\title{
The Effort to Increase the Students' Achievement in Poetry Mastery through Semiotic Method
}

\author{
I Wy. Dirgeyasa \\ English Department, State University of Medan, Indonesia \\ E-mail: wayandirgayasa@yahoo.com
}

Doi:10.7575/aiac.alls.v.8n.1p.104

Received: 06/10/2016

URL: http://dx.doi.org/10.7575/aiac.alls.v.8n.1p.104

Accepted: 08/01/2017

\begin{abstract}
The obejectives of this research are to know the improvement of the students' achievement in poetry mastery and their perception regarding to the semiotic method in teaching and learning poetry in English Education Department, Languages and Art Faculty of State University of Medan. The research method used is the Classroom Action Research (CAR). The subjects of the research are the fifth semester of 37 students of 2013/2014 academic year. The data are collected by test in order to know the students' achievment in poetry mastery. The students' perception toward the implementation of the semiotic method for teaching and learning poetry is collected by questionaire. The data are analyzed by descriptive analysis. The result of research shows that (1) the average score of the students' achievement of poetry mastery is $(71.75)$ or it increases $(11,59)$ point from pre-test $(60.16)$ and (2) in general, the students' perception toward the semiotic method for teaching and learning poetry are good and positive.
\end{abstract}

Keywords: semiotic method, poetry, perception, and learning achievment

\section{Introduction}

It is generally known that to understand the meaning of poetry is truly difficult to do not only for the students but also the lecturers as well. It is really the most difficult subject to do among other literary works such as drama, prose, short story and, etc. This may happen becuase the poetry has its unique and distinctive features such as physical structure, linguistic features and mental structure as well. In line with the difficulty to understand and grasp the meaning of the poetry, Pradopo (1994) states that the poetry does not only has its unique physical and mental structure but it also provides intepretation of what is written textually. In line with Pradopo's (1994) statement, Nurgiyantoro (2005) adds that the difficulty to understand the meaning of the poetry is due to its essesnces of having a) esthetic, b) indirect expression, and c) compression.

Besides that, the difficulty to understand the poetry also happens because the poetry principly uses language as medium. In fact, before the language is used as medium for poetry, the language itself has already its own meaning following the language rules and patterns which must be known and mastered by the students. For this reasons, Premigner in as quoted by (Pradopo, 1994) in Jabrohim, ed (2001) states that the meaning of language before it is used as medium for literary work (poetry), is called the first oder semiotics.

To understand and grasp the meaning of poetry well and closely as what the writer want to deliver, the students need to know the relevant and the good method and strategy on how to understand the poetry. The prompt method will then help the students understand the meaning of the poetry correctly and promptly as what the writer wants to. The method or strategy used for understanding literary poetry, is of course different from common method or strategy used for teaching and learning for language skills such as speaking, reading, and writing or language components such as vocabulary, grammar, etc and or even other subjects related to English, for example, syntax, morphology, phonology as well.

Regarding to poetry subject, in English Language and Literature Department, Faculty of Languages and Arts, State University of Medan, it is taught and learnt for two semesters (English Department, Faculty of Languages and Arts, State University of Medan's Curriculum, 2004). By this subject course, the students are expected to be able to appreaciate and understand the meaning of the poetry well. Then, consequently the knowledge and competence of appreciation and understanding will also fasilitate and help students understand and master other literary works such as darama, prose, short story, etc. In addition, poetry course also significantly widens and improves the mastery of the language skills and language components as well.

However, the students' learning achievment of poetry subject are not really satisfactory yet. In other word, their poetry subject learning achievments are relatively low. For example, by the 2012/2013 academic year of the 67 students taken the subject shows that the students' achievment of poetry in English Language and literature Department, Faculty of Languages and Arts, State University of Medan are relatively low in average. For example, $(11.76 \%)$ of the students gets grade (A), (23.88\%) of the students gets grade (B), and most of the students approximately (52.23\%) still reaches 
(grade (C), while the rests of the students get grade (D) and (E) respectively $(7.46 \%)$ and $(4.47 \%)($ Self-Evaluation,SE) English Language and Literature Department, Faculty of Languages and Arts, State University of Medan, 2013).

As a matter of fact, there are some factors determining the success or failure of teaching and learning such as the materials, teaching and learning method, assessment, media, motivation, etc. Those become influencing factors whether the teaching and learning will be successful or not. Referring to the above statement, Fathurrohman and Sutikno (2007; Hamalik, 2007); Kitao,2014) adds that the components affecting the process of teaching and learning are the objectives, learning materials, teaching and learning method, learning resources, assessment, the teacher, and the students. Then, Harmer (2007) states that the success and the failure of the teaching and learning process depend much on the reality of the students input, teaching and learning process, teacher's competence, assessment, motivation, etc.

Among others affecting factors, the teaching strategy plays the important role whether the teaching and learning process successful or not (Brown, 2004). This happens becuase the teaching strategy determines and drives the students what and how to do during the process of teaching and learning. By implementing the relevant teaching strategy, it is generally believed that the teaching and learning will be succesful (Djojosubroto, 2006; Harmer (2007).

In pertaining to the teaching strategy for poetry subject, theoretically and empirically semiotic method can be used for teaching and learning poetry Fananie (2004; (Ratna, 2004; Djojosubroto, 2006; Pradopo, 2009). Then, Ansari and Dirgeyasa (2013) also proposes that the implementation of semiotic method for analysing the poetry will facilitate the students more easily to know the meaning of poetry because they know what to and how to systematically and in order to understand the meaning of the poetry.

In line with the semiotic method, Riffatrre (1978) in Jabrohim (2001) states that semitoic method as teaching and learning poetry is really relevant as a teaching and learning for poetry subject. Basically the semiotic approach is a systematic and procedural teaching and learning strategy in order to know and find out the meaning of the poetry comprehensively. It is assumed that the learning achievment of poetry will be improving and succesful due to its tight systematic and procedural steps. This research aims at examining the improvement of the students' achievement in poetry mastery and their perception regarding to the semiotic method in teaching and learning poetry in English Education Department, Languages and Art Faculty of State University of Medan.

Historically, the study of semiotics has grown and developed for ages, however the semiotic study for literary work has just developed rapidly since the 20th century (Ratna, 2004). Then, (Lotman, 1977) in Pradopo (2009) states that the language of literary is the language of second model in which it is full of metaphore, connotation, and other possible typical multiple interpretation. He, then states that the language of literary is a model of communication system with full of culture values and system. In short, it can be said that the language of literary is the culture itself with its distinctive features and attributes.

Generally semiotic as a science views social and cultural phenomena as sign system Preminer (1974) in Pradopo (2003; Ratna, 2004; Wiyatmi, 2006). In terms of literary work (hereafter poetry), the semiotic method also views poetry as sign of system as well. The language as a medium in poetry itself is also as a matter of sign which already has its own meaning. This leads to the difference between poetry and other literary works such drama, novel, etc (Pradopo, 2009).

The language of literary is also a matter of sign (language) needs interpretating. It also uses the language as a medium in order to convey its meaning. The language of the poetry is a sign which needs the holistic and comprehensive interpretation in order to grasp its meaning correctly. Referring to the relationship between semiotic study and the study of literary work, Culler (1981) as quoted by Pradopo (1994) in Jabrohim, ed. (2001) strongly states that in terms of the essence and the semiotics study of the literary work, there are two level of meaning systems namely the first order semiotics and the second order semiotics.

The first order semiotics refers to the meanings are provided by language rules or system itself. This meaning is actually pure meaning based on the language system and convention textually without being interpreted socially contextual. Preminger (1974) in as quoted by Pradopo Pradopo (1994) in Jabrohim, ed. (2001) states that the further implementation is to provide literary meaning within the second order semiotics. This is the meaning of the language in literary work so that the literary meaning is called significances or meaning of meaning or significance meaning.

Based on the semiotics study concerning to the study of signs, so the important signs are searched for in order to deliver the meaning of literary work whether the signs are icon, index, and or symbol. That's why, to understand and grasp the meaning of poetry is a kind of hunting the signs themselves Riffatrre (1978) in Pradopo (2003). Moreover, the semiotic study (hereafter the semiotic method) with its typical characteristic and attributes is a certain method that can be used to find out the meaning of icon, index, and symbol in the literary work.

The study of poetry by semiotic method, is basically to find out the meaning of poetry through systematic steps and procedures. The steps for understanding and grasping the meaning of poetry by semiotic method is done in four ways. They are a) heuristic reading, b) rectroactive or hermaneutic reading, c) reading matrix or key word, and d) searching of theme (Riffatrre,1978) as quoted by Pradopo in (Jabrohim, 2001).

The heuristic reading refers to reading of poetry in according to the convention structure of the language. It means that reading of peotry must refer to conventions and rules of a certain linguistic system or first order semiotics. This may be different from one language to another language.

Then, Pradopo in Jabrohim, ed (2001) states that this type of reading sometimes involves rereading in line with the language system itself. Principly, the heuristic reading is a kind of reading peotry based on normative strucutre, 
marfology, semantic, and syntatic system. This level of reading, then will provide the meaning of poetry in accordance to the structure of peotry itself within the normative convention of the language use. The meaning provided by this model of reading is textual meaning. The result of this reading does not provide the real meaning of poetry expected by the reader. In other word, it is called first order semiotics (Riffatrre,1978) as quoted by Pradopo (1994) in (Jabrohim, 2001).

The retroactive or hermeneutic reading is regarded as a second order semiotics. This model of reading tries to find out the meaning of the poetry contextually either linguistics or social domains. By retroactive or hermeneutic reading, the meaning of poetry is will be closer to meaning conveyed by the poet. This could be possible because it provides interpretation or interpretative meaning (hermeneutic). The hermeneutic reading refers to finding the meaning of the language by literary convention or rules. This happens due to the usage of many connotation, metaphores, ambiguity, or even personafication in the poetry.

The next step is to do the search or reading the matrix or key word. This is done because sometimes the retroactive or hermeneutic reading does not automatically provide the optimal and real meaning of the poetry (Riffaterre,1978) as quoted by Pradopo in (Jabrohim, ed. 2001). So that it is really necessary to do reading matrix or key word then it is followed up to know the theme of the poetry because it facilitate to know the meaning of the poetry. By reading matrix or key word, the meaning of poetry tends much to be optimal. As a matter of fact, the keyword is not always in terms of word which is written down in the poetry textually. It is sometimes implicite, that is why it is necessary to concrete it in the form of words (explicite).

It is generally known that the matrix is also a kind of keyword. The matrix actually leads to theme but a matirix is not a theme. By matrix, the theme will be known easily. Theme is the central idea or issue of a certain poetry (Riffaterre,1978) as quoted by Pradopo(1994) in (Jabrohim, ed. 2001). By having the central idea or issue of the poetry, finally the meaning of a certain poetry is formulated in order to find out the intergrated meaning of the poetry. This means that the real meaning of the poetry is provided by the long and systematic process under semiotic methods. In short, it could said that the meaning of the poetry is a matter of integrated meaning of all process of semiotic method.

In line with the description above, the obejectives of this research are to know the improvement of the students' achievement in poetry mastery and their perception regarding to the semiotic method in teaching and learning poetry in English Education Department, Languages and Art Faculty of State University of Medan.

\section{Research Methodology}

This research is carried out at English Language and Literature Department, Faculty Languages and Arts, State University of Medan in the academic year of 2013/2014. The research method used is classroom action research (CAR). The subject of the research is the fifth semester students consisting of 37 students academic year. The object of the study is William Carlos William's poetry entitled Spring and All. The data are collected by test in order to know the students' achievment in poetry mastery. Then, the students' perception toward the implementation of the semiotic method for teaching and learning poetry is collected by questionaire. Then, the data are analyzed by descriptive analysis.

\section{The Findings and Discussion}

\subsection{The Findings}

This research is done in two cycles. The first cycle consists of a) pre test, b) teaching and learning process, and c) post test. Then the second cycle covers a) teaching and learning process and b) post test or the final test of the research for the whole research process. In terms of data, this research consists of quantitative and qualitative data. The quantitative data are the students' achievment in poetry mastery. Then, the qualitative data are the students' perception toward semiotic method for teaching and learning poetry. Based on the data of the research, the overal students' achivement in poetry mastery are shown on the table 1 below.

Table 1. The overal students' achievement in poetry

\begin{tabular}{lllll}
\hline No & Description & T1 & T2 & T3 \\
\hline 1 & The Highest score & 70 & 80 & 87 \\
2 & The Lowest Score & 54 & 58 & 59 \\
3 & The average & 60.16 & 65.21 & 71.75 \\
\hline Marks: & & & \\
$T 1 \quad=$ pre test & & \\
$T 2 \quad=$ post test cycle I & & & \\
$T 3 \quad=$ post test II & & &
\end{tabular}

Based on table 1 above, it shows that the highest score of pre-test is (70), the lowest score is (54), and the average score is (60.16). Then, the highest score of post test of cycle $\mathrm{I}$ is (80), the lowest score is about (58), and the average score is 
(65.21). Finally the highest score is about (87), the lowest one is (59), and the average score is (71.75) at the end of the research or cycle II.

However, in detail, generally the students' entry behavior (pre-test) of poetry mastery is relatively low as shown on table 2 below.

Table. 2 The result of pr- test of students' achievment in poetry mastery

\begin{tabular}{lllll}
\hline No & Range & F & Percentage & Mark \\
1 & $80-100$ & 0 & 0.00 & Very good \\
2 & $70-79$ & 3 & 8.10 & Good \\
3 & $60-69$ & 16 & 43.24 & Fair \\
4 & $55-59$ & 17 & 45.94 & Poor \\
5 & $0-54$ & 1 & 2.70 & Very poor \\
Total & & 37 & 100 & \\
\hline
\end{tabular}

Table 2 above shows that none reaches grade (80-100) or very good. The student having good achievement ranging (7079 ) is only (8.10\%). However, most of them respectively (43.24\%) and (45.94\%) of the students' achievment in poetry mastery are regarded fair and poor.

After the semiotic method is implemented for 4 (four) times in teaching and learning poetry, the students' achievment in poetry mastery improves even though the students' achievement does not reach the indicator targeted score ranging from (70-79) in average at the end of the study. The various distribution of students' achievment in poetry mastery is shown by table 3 below.

Table 3 The result of post test of the students' achievment in poetry mastery in cycle I

\begin{tabular}{lllll}
\hline No & Range & F & Percentage & Mark \\
1 & $80-100$ & 1 & 2.70 & Very good \\
2 & $70-79$ & 8 & 21.26 & Good \\
3 & $60-69$ & 22 & 59.45 & Fair \\
4 & $55-59$ & 6 & 16.21 & Poor \\
5 & $0-54$ & 0 & 0.00 & Very poor \\
Total & & 37 & 100 & \\
\hline
\end{tabular}

In line with table 3 above, the distribution of the students' achievment in poetry mastery is relatively different from the pre-test achievment. The students achieving (80-100) point or very good is about (2.70\%) and (21.26\%) of the students' achievment is categorized good (70-79). However, almost (60\%) of the students' achievment is still categorized fair. But none of them is reaching very poor achievement ( 0-54) point.

After cycle I ends, the students are also given questionairre in order to know the problems and constraints of the implementation of semiotic method for teaching and learning poetry. By providing 10 (ten) statements and or questions, there are five major problems or constraints in which the teaching and learning process does not succeed well. The five (5) major problems and constraints are shown by table 4 below.

Table 4. The main five problems and constraints of teaching and learning poetry in cycle I

\begin{tabular}{llll}
\hline No & Range & F & Percentage \\
1 & Insufficient time for learning & 7 & 18.91 \\
2 & Difficult sample of poetry & 10 & 27.02 \\
3 & Model of student interaction & 15 & 40.54 \\
4 & Semiotic learning strategy & 2 & 5.40 \\
5 & Limited time for testing & 3 & 8.10 \\
Total & & 37 & 100 \\
\hline
\end{tabular}

Referring to table 4 above, the main problems or constraints in teaching and learning poetry hierarchily are 1) model of student interaction $(40.54 \%), 2)$ difficult sample of poetry $(27.02 \%)$, 3) insufficient time for learning $(18.91 \%)$, 4) limted time for testing (3.10\%), and semiotic learning strategy $(5.40 \%)$. 
By having the problems and constraints above, then they are adjusted and improved in order to minimaze the problems and constraints themselves for the next cycle (cycle II). In addition, the revisions, adjustment, and improvement are also needed in order to provide optimal teaching and learning process. The teaching and learning process for the cycle II are conducted for 4 (four) times. The result of the post test of the poetry mastery in cycle II (the end of the research) is shown by table 5 below.

Table 5. The result of post test of students' achievment in poetry mastery in cycle II (the end of the research)

\begin{tabular}{lllll}
\hline No & Range & F & Percentage & Mark \\
1 & $80-100$ & 4 & 10.81 & Very good \\
2 & $70-79$ & 17 & 45.94 & Good \\
3 & $60-69$ & 15 & 40.54 & Fair \\
4 & $55-59$ & 1 & 2.70 & Poor \\
5 & $0-54$ & 0 & 0.00 & Very poor \\
\multicolumn{7}{l}{ Total } & 37 & 100 &
\end{tabular}

Table 5 above shows that the students' achievment in poetry mastery increases signficantly and relatively proportional. The students reaching a very good category or $(80-100)$ is about $(10.81 \%)$. And most of them $(45.94 \%)$ is reaching good score ranging (70-79) point and students having fair category is about (40.54\%). While only $(2.70 \%)$ of them has poor score and none get very poor score $(0-54)$ point.

\subsection{Discussion}

Teaching and learning poetry through semiotic method improves the students' achievement in poetry mastery and changes the students' perception toward semiotic method. The overall of the students' achievement in poetry master is from pre-test (T1), post-test of cycle I (T2), and post-test of cycle II or the end the research y is shown by table 6 below.

Table 6. The overall students' achievement in poetry mastery

\begin{tabular}{llllll}
\hline No & Range & T1 & T2 & T3 & Mark \\
1 & $80-100$ & 0.00 & 2.70 & 10.81 & Very good \\
2 & $70-79$ & 8.10 & 21.26 & 45.94 & Good \\
3 & $60-69$ & 43.24 & 59.45 & 40.54 & Fair \\
4 & $55-59$ & 45.94 & 16.21 & 2.70 & Poor \\
5 & $0-54$ & 2.70 & 0.00 & 0.00 & Very poor \\
Total & & 100 & 100 & 100 & 100 \\
\hline Marks: & & & & & \\
T1 & $=$ pre test & & & & \\
T2 & post test cycle I & & & & \\
T3 & post test II & & & &
\end{tabular}

Table 6 above shows that none or $(0.00 \%)$ gets very good achievement in pre-test (hereafter T1) but in post of test cycle I (hereafter T2), it is about $(2.70 \%)$ and in post test cylcle II (hereafter T3) becomes $(10.81 \%)$. The most significant achievement is students providing good score $(45.94 \%)$ after the end of the research. In fact in (T2), it is about $(21.26 \%)$ and it is only $(8.10 \%)$ in (T1). However, the students's achievement providing fair score is relatively fluctuative ranging $(43.24 \%)$ in (T1), $(59.45 \%)$ in (T2), and finally $(40.54 \%)$ in (T3). Then, the most significant decrease achievement of the students is the students having poor score from (45.94\%) in (T1) to be (16.21\%) in (T2), and $(2.70 \%)$ in $(\mathrm{T} 3)$ respectively.

The significant achievement and improvement of students poetry mastery shows that teaching and learning or teaching method influences the success and the failure of the students' achivement in learning. A good and relevant teaching and learning method finally lead to the success of the teaching and learning and otherwise. In accordance to the significance of teaching method, (Brown (2004; Djojosubroto, 2006; Harmer, 2007) states that the success and the failure of the teaching and learning process depend much on the reality of the students input, teaching and learning process, teacher's competence, assessment, motivation, etc.

By referring the results of the research above, it shows that the semiotic method really really provides the significant contribution toward the students achievement in teaching and learning poetry. It proves that semiotic method can improve the students' achievement in poetry mastery significantly (60.16) point in (T1) and (71.75) point in (T3) in average. This condition is relevant to what Preminger (1974) in Pradopo (2003) states that the further implementation 
is to provide literary meaning within the second order semiotics. This trully help and facilitates the students in teaching and learning process.

In addition, Djojosubroto (2006) states that teaching and learning poetry is really difficult to do both by the teacher and students. She further reports that teaching and learning poetry by semiotic method really helps them how to understand and comprehend the poetry step by step and gradually. The semiotic method provides a systematic way to learn to understand the poetry. By this method the students are not learning by trial and error method because this method really guides the students to understand the poetry step by step (Preminger,1974) in (Pradopo 2003; Ratna, 2004; Fannnie, 2006)). In addition, in many cases, so far the students tend to fail to understand the meaning of the poetry because they learn to understand by 'trial and error' method and the lecturers tend let them find the meaning without any systematic steps (Paniagua, 2009). By semiotic method, the students seemingly find the new way how to understand the poetry and it really helps them to study the poetry (Wardarita, 2007; Ansari and Dirgeyasa, 2013).

At the end of the research, the students are then given a questioanirre containg 5 (five) items such as relevant, interesting, motivating, positive, and critical and analytical. This questinairre is used to find out the students' perceptions toward the implementation of the semiotic method in teaching and learning poetry. The results of the questionairre is shown by table 7 below.

Table 7 The students' perceptions toward semiotic method for teaching and learning poetry

\begin{tabular}{llll}
\hline No & Description & F & Percentage \\
1 & Relevant & 10 & 27.02 \\
2 & Interesting & 5 & 13.51 \\
3 & Motivating & 6 & 16.21 \\
4 & Positive & 9 & 24.23 \\
5 & Critical and analytical & 7 & 18.91 \\
Total & & 37 & 100 \\
\hline
\end{tabular}

Based on the table 7 above, it shows that most of the students $(27.02 \%)$ states that semiotic method is relevant for teaching and learning poetry. Then, respectively $(24.23 \%)$ and $(18.91 \%)$ students states that it is positive method and provides critical and analytical thought. While $(13.51 \%)$ and $(16.21 \%)$ of the students states that semiotic method is quite motivating and interesting.

This happens because semiotic method provides the students the systematic way and procedure how to understand and master the poetry. Culler (1981) as qouted Pradopo in Jabrohim, ed. (2001; Kull, 2011) strongly states that in terms of the essence and the semiotics study of the literary work, there are two level of meaning system that is the first order semiotics and the second order semiotics. These are really helpful to facilitate to understand the literary work in a such complex way.

\section{Conclusion}

In line with the results of the research and discussion, the semiotic method really helps and facilitates the students to understand the meaning of poetry. It is clearly proved that during the implementation of semiotic method, the students' achievement in poetry mastery improve respectively (60.16) in (T1), (65.21) in (T2) and (71.75) point in (T3). By this method, the students learn poetry step by step in systematic way and they find the meaning from textually to finally contextually. Then, the semiotic method can provide critical and analytical thought for the students and motivate them to learn poetry. For the lecturers, due to the difficulty of the understanding the poetry, the lecturers should work hard to find out, select, and modify the teaching method, subject particularly the poetry taught and learnt for the students.

\section{References}

Ansari, Khairil and Dirgeyasa I Wy. (2013). Analisis Makna Puisi King, Jr's 'I Have a Dream'(The Analysis of Meaning of King Jr's Poetry "I Have a Dream") dalam Sastra Indonesia Berakar Pada Sastra Daerah Menuju Sastra Dunia. Proceeding. Bandung : Penerbit UNPAD Press, p.66.

Brizee, Allen and Tompkins, J. C. (2009). Theory and Schools of Criticism. In (http:/owl.english.purdue.edu) assessed on January 28, 2009.

Brown. H. Douglas. (2004). Language Assessment: Principles and Classroom Practice. New York: Pearson Education. Inc.

Budianto, M. et al. (2002). Membaca Sastra (Reading Poetry). Jakarta: Indonesiatra.

Djojosubroto, Kinayati. (2006). Pengajaran Puisi dan Pemahaman (Teaching Poetry and Its Comprehension). Bandung: Nuansa.

Endraswara, S. (2008). Metode Penelitian Psikologi Sastra (Research Methodolgy for Literature Psychology). Yogyakarta: MedPress. 
Fananie, Zainuddin. (2011). Telaah Sastra (The Study of Literature). Surakarta: Muhammadyah University Press.

Hamalik, Umar. (2007). Perencanaan Pengajaran Berdasarkan Pendekatan Sistem (A Systemic Approach for Teaching Planning). Bandung: Bumi Aksara.

Harmer, Jeramy. (2007). The Practice of English Language Teaching, $4^{\text {th }}$ ed. London: Longman Pearson.

Hoed, H. B. (2008). Semiotika dan Dinamika Sosial Budaya (Semiotic and Social and Cultural Dynamics). Jakarta: Universitas Indonesia.

Jabrohim, ed. (2001). Metodologi Penelitian Sastra (Literature Research Methodology). Yogyakarta: Hanindita.

KBK Curriculum. (2004). English Department of Faculty of Languages and Arts, State University of Medan.

Kennnedy.X.J.(1979). Literature: An Introduction to Fiction, Poetry, and Drama. Boston: Little, Brown and Company.

Kitao, Kenji. Selecting and Developing Teaching and Learning Materials in http//itself.org/article/Kiato-material htm/7/26/2014.

Kull, Kalevi. (2011). Juri Lotman in English: Bibliography. Sign Systems Studies 39(2/4), 2011, p.343.

Masinambow, E.M.K, and Hidayat., S.R. (2001). Semiotik Mengkaji Tanda dalam Aritfak (Semiotics the Study of Signs and Artifact) Jakarta: Balai Pustaka.

Nurgiyantoro, B. (2005). Sastra Anak (Children Literature). Yogyakarta: Gadjah Mada University Press.

Paniagua, M. Zalbidea. (2009) Cultural Studies through Literary and Semiotic Approaches: A Review Article of New Manuals by Walton and Thwaites, Davis, and Mules in CLC Web: Comparative Literature and Culture. Vol. 11. Issue.4. p.8.

Pradopo, R. D. (1994). Prinsip-Prinsip Kritik Sastra (The Principles of Literary Criticism). Yogyakarta: Gadjah Mada University Press.

2003. Beberapa Teori Sastra, Metode Kritik, dan Penerapannya (Literary Theories, Critic Method, and Its Implementation). Yogyakarta: Pustaka. 2009. Pengkajian Puisi. Yogyakarta: Gadjah Mada University Press.

Ratna, N. K. (2004). Teori, Metode, dan Teknik Penelitian Sastra (Theory, Method, and Literature Research Technique) Yogyakarta: Pustaka Pelajar.

Self-Evaluation. (2013). English Language and Literature Department, Faculty of Languages and Arts, State University of Medan. Medan.

Segersi,T.Riem.1978. Evaluasi Teks Sastra (Evaluation of Literary Text), terjemahan Suminto. A. Sayuti.Yogyakarta: Adicita.

Siegel, Kristi, 2009. Introduction to Modern Literary Theory. In

(http://www.Kristisiegel.com/theory.htm. Assessed on March 02, 2011.

Siswanto, W. 2008. Pengantar Teori Sastra (Introduction to Literary Theory). Jakarta: Grasindo.

Sutikno, Sobry and Fathurrohman, Pupuh (2007). Strategi Belajar Mengajar (Teaching and Learning Strategy). Bandung: Refika Aditama.

Wardarita, R. 2007. Kajian Struktural-Semiotik Dalam Puisi-Puisi Karya Chairil Anwar (The Structural-Semiotics Study of Khairil Anwar's Peotry) Journal Mandiri (9) 4.

Wellek, R. dan Austin Warren. 1995. Teori Kesusastraan (Literary Theories) Jakarta: Gramedia

Wiyatmi. 2006. Pengantar Kajian Sastra (Introduction to Literary Study). Yogyakarta: Pustaka Book Publisher. 